\title{
Palliative care production for health professionals in the context of home care
}

\author{
A produção de cuidados paliativos por profissionais de saúde no contexto da assistência domiciliar
}

La producción de atención paliativa por profesionales de la salud em el contexto de la atención em el hogar

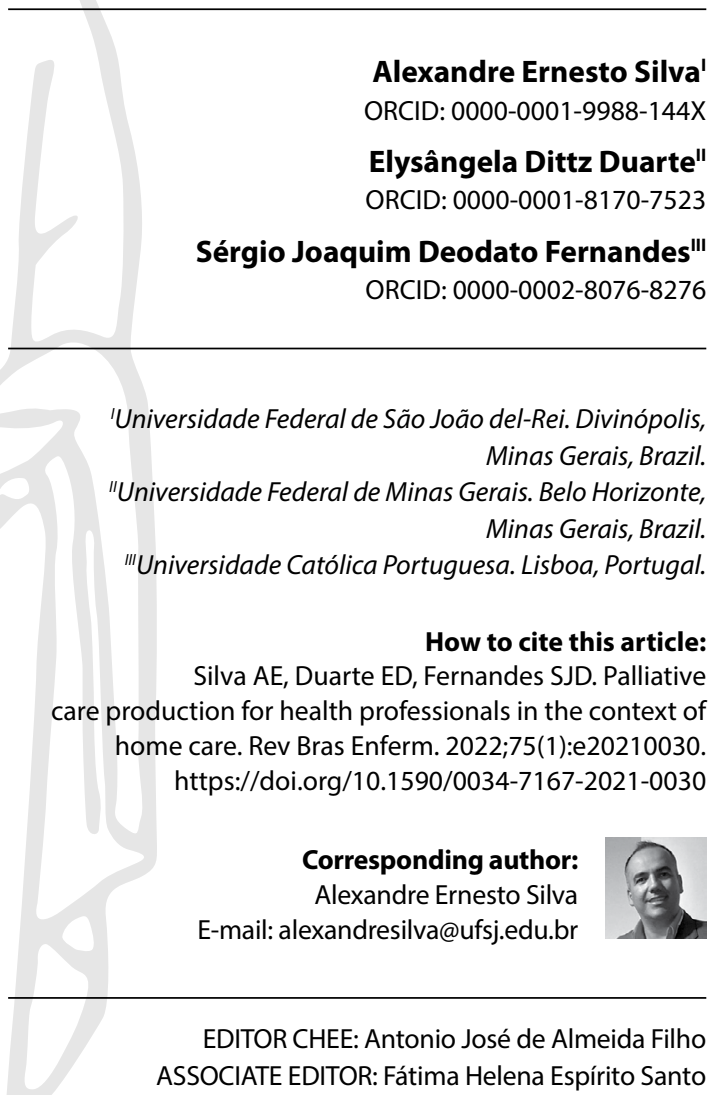

Submission: 01-18-2021 Approval: 03-09-2021

\begin{abstract}
Objectives: to analyze palliative care production developed by health professionals to home care patients. Methods: this is an exploratory study, with a qualitative approach, using the transpersonal care theoretical framework. Thirteen interviews were conducted with health professionals and 18 observations were conducted on different cases. Content analysis was performed using MAXQDA ${ }^{\circ}$. Results: actions performed: maintenance and follow-up measures to people eligible for palliative care, in acts of dialogue and "listening" to caregivers and users, conducting guidelines for the care and self-care process, performing technical procedures, delivery of materials, referrals and medical prescriptions to users. Final Considerations: it is perceived the need for advances in the implementation of government policies in Brazil that insert palliative care into the Health Care Network through educational, managerial and care actions that ensure human dignity, thus allowing the development of these and other palliative care interventions.

Descriptors: Palliative Care; Caregivers; Health Personnel; Home Nursing; Delivery of Health Care.
\end{abstract}

\section{RESUMO}

Objetivos: analisar a produção dos cuidados paliativos desenvolvidas por profissionais de saúde a pacientes da atenção domiciliar. Métodos: estudo exploratório, de abordagem qualitativa, utilizando o referencial teórico do cuidado transpessoal. Foram realizadas 13 entrevistas a profissionais de saúde e 18 observações a casos distintos. Realizou-se análise de conteúdo, utilizando-se MAXQDA ${ }^{\circ}$ software. Resultados: ações realizadas: medidas de manutenção e acompanhamento às pessoas elegíveis aos cuidados paliativos em atos de diálogo e "escuta" aos cuidadores e usuário, realização de orientações para o processo de cuidado e autocuidado, realização de procedimentos técnicos, entrega de materiais, encaminhamentos e receitas médicas aos usuários. Considerações Finais: percebe-se a necessidade de avanços na implementação de políticas governamentais no Brasil que insiram os cuidados paliativos na Rede de Atenção à Saúde por meio de ações educacionais, gerenciais e assistenciais que assegurem a dignidade humana, permitindo desenvolver essas e outras intervenções de cuidados paliativos.

Descritores: Cuidados Paliativos; Cuidadores; Pessoal de Saúde; Assistência Domiciliar; Atenção à Saúde.

\section{RESUMEN}

Objetivos: analizar la producción de cuidados paliativos desarrollados por profesionales de la salud para pacientes domiciliarios. Métodos: estudio exploratorio, con abordaje cualitativo, utilizando el marco teórico del cuidado transpersonal. Se realizaron 13 entrevistas a profesionales de la salud y 18 observaciones de diferentes casos. El análisis de contenido se realizó utilizando el software MAXQDA ${ }^{\circ}$. Resultados: acciones realizadas: medidas de mantenimiento y seguimiento de las personas elegibles para cuidados paliativos en actos de diálogo y "escucha" a los cuidadores y usuarios, orientando el proceso de cuidado y autocuidado, realización de trámites técnicos, entrega de materiales, derivaciones y asistencia médica. prescripciones para los usuarios. Consideraciones Finales: es necesario avanzar en la implementación de políticas gubernamentales en Brasil que incluyan los cuidados paliativos en la Red de Atención de Salud a través de acciones educativas, gerenciales y asistenciales que aseguren la dignidad humana, permitiendo el desarrollo de estas y otras intervenciones de cuidados paliativos.

Descriptores: Cuidados Paliativos; Cuidadores; Personal de Salud; Atención Domiciliaria de Salud; Atención a la Salud. 


\section{INTRODUCTION}

The world population is undergoing a process of demographic transition resulting from reduction in fertility rates, decrease in infant mortality and consequent increase in life expectancy and the number of older adults ${ }^{(1-2)}$. This context is simultaneous to the change in the epidemiological profile of the Brazilian population, with a clear increase in the prevalence of Chronic Noncommunicable Diseases (NCDs), responsible for approximately $72.6 \%$ of deaths worldwide ${ }^{(1,3-4)}$.

With the aging population and the increase in NCDs, it is believed an increase in the rate of dependence of people and the time they will need care. Thus, the need for palliative care in health care networks is reaffirmed, with the aim of, through relief and prevention of suffering, promoting human dignity, quality of life (QoL) and adaptation to new forms of life of users and their families ${ }^{(1,5)}$.

According to the World Health Organization (WHO) ${ }^{(6)}$, palliative care is an approach that improves the lives of people who face diseases that threaten the continuity of life, preserving human dignity and promoting QoL through the relief of biopsychosocial and spiritual suffering. The benefits of palliative care also extend to the relatives of persons cared for.

In Brazil, palliative care is operationalized in hospitals, hospices, specialized outpatient clinics and home care services, however, with limitations, due to the higher number of eligible users in relation to the number of beds available for this modality of care ${ }^{(1,7)}$. Among the service settings that include palliative care, home care $(\mathrm{HC})$ stands out in the present study. This modality of care, to actions for the prevention and treatment of diseases, rehabilitation, palliative care and health promotion, provided at home, are integrated and organized as home care service (HCS). Through this design, we seek to ensure continuity of care and actions articulated with the other units and services of the Health Care Network (RAS - Rede de Atenção à Saúde) ${ }^{(1,7)}$.

It is considered that the continuity of daily social relationships, one of the aspects that promotes dignity for the person cared for and their family members ${ }^{(8)}$, is favored when it is possible to develop palliative care at home.

With the absence of a specific public policy for palliative care in Brazil, the Ministry of Health, in order to favor this type of assistance in $\mathrm{HC}$, defines actions to guide the work of $\mathrm{HC}$ teams in caring for people eligible for palliative care and their relatives. The established actions were created aiming to contemplate patient comfort through effective control of symptoms, effective communication and family support, and preparation for home death ${ }^{(9)}$. These actions signal the performance of palliative care in $\mathrm{HC}$, but they do not guarantee by themselves that these are being contemplated in $\mathrm{HC}$ practice in Brazil.

These actions established by the Ministry of Health are consistent with Jean Watson's Theory of Transpersonal Care, the theoretical framework used in this study, due to its agreement with the philosophy and principles of palliative care In Watson's theory, the human being is the central point to which all care actions must converge. The theorist describes that "the moral ideal of caregivers must aim at protecting, improving and preserving human dignity"(1,10).
The reflection on the care practice and the challenges for the guarantee of human dignity, through palliative care, raise the following questions: what are the palliative care actions, in the context of HC services of the Brazilian Unified Health System (SUS - Sistema Único de Saúde), have been produced?

The relevance of the development of this research was reinforced by the incipient scientific production about palliative care actions in $\mathrm{HC}$ in Brazil(1).

\section{OBJECTIVES}

To analyze palliative care production developed by health professionals to home care patients of the Unified Health System.

\section{METHODS}

\section{Ethical aspects}

The research complied with Resolution 466/2012 $2^{(11)}$. The project was approved by the Institutional Review Board of Universidade Federal de Minas Gerais (UFMG), proven by CAAE (Certificado de Apresentação para Apreciação Ética - Certificate of Presentation for Ethical Consideration) 59795716.7.0000.5149 and Opinion $1,803,756$, after the approval of the municipality under study. All participants signed an Informed Consent Form ${ }^{(1)}$.

\section{Type of study}

This is a descriptive-exploratory study of qualitative approach anchored in the theoretical framework of Jean Watson's transpersonal care. The single case study was adopted as a research strategy ${ }^{(1)}$. The Consolidated Criteria for Reporting Qualitative Research (COREQ) was used to guide the writing of the article.

\section{Sample and inclusion criteria}

Intentionally included as a reference setting with the Ministry of Health in HC, three multidisciplinary HC teams and a multidisciplinary support team from HCS of a city in the greater Belo Horizonte - Minas Gerais for data collection, contemplating people from different teams, locations and realities of the municipality under study, as Yin ${ }^{(1,12)}$, advises, when dealing with a single case study.

Participant observations were made in 18 different cases, through home visits, and 13 health professionals were interviewed, who were members of these teams. It was considered as inclusion criteria for the interview to work in the service for at least 6 (six) months and to be in professional practice during the period of study ${ }^{(1)}$.

\section{Data collection}

The option for the case study requires the use of multiple data sources using participant observation and interview ${ }^{(12)}$. Data collection was carried out between January and March 2017.

Participant observation consisted of the researcher's entry into the reality to be studied, to ascertain the aspects pertinent to professionals' actions in their activities through home visits and record in a field diary ${ }^{(1,13)}$. 
The interviews were conducted at HCS' headquarters, in private places, determined by participants, maintaining information privacy and confidentiality. A semi-structured script was used for the interview, which consisted of questions that characterized professionals and guiding questions of the interview itself. The reports were recorded using an MP4 player and later transcribed for analysis ${ }^{(1)}$.

The number of participants was not stipulated a priori, having been established throughout the study according to data saturation criteria. Data saturation is achieved when the researcher reaches the depth and breadth of information, answering the question of the elaborated research ${ }^{(1,14)}$. In this study, data saturation was considered from the moment when new observations and interviews did not bring data that differentiates from the information already obtained, when considering that this information was able to answer the research question.

The interview participants were identified, sequentially, in the interviews, by the E1 coding (interviewee 1). In the participant observation, each situation followed was identified in a field diary (FD) and its respective page. Health professionals, on the other hand, were identified by the profession and the sequence number of the team monitored during visits, for example, team doctor 1 - doctor 1 , and so on. The exception was only when the team had two nursing technicians (NT) When this happened, we identified, for instance, as nursing technician $1 \mathrm{~A}$, i.e., the profession, the team followed and A or B to identify the two professionals of the same category in a single visit ${ }^{(1)}$.

To characterize the health professionals interviewed and followed in home visits, the identification of profession, age, job tenure, time of training and experiences prior to their performance in HCS were carried out ${ }^{(1)}$.

In the present study, participant observations were initially carried out during home visits, with the objective of observing the relationships established to know the daily routine regarding palliative care practice in HC. These observations were described in FD, and, after reading, narratives of each followed case were elaborated. Such narratives were constructed with the purpose of presenting, in an organized manner, each followed case, revealing the uniqueness of each one in the process of home visits. However, for data analysis, the context of HCS as a whole was verified. Then, the interviews were conducted, guided by a semi-structured script, recorded and later transcribed in full. For data storage, the coding and validation process between coders, MAXQDA', version 12, was used ${ }^{(1)}$.

\section{Data analysis}

Content analysis was used to analyze the data. This is a type of analysis used when a study aims to describe a phenomenon or event, working with the content, materiality and empirical conditions of the text and establishing categories for its interpretation ${ }^{(1,15)}$.

In this study, in which palliative care actions in $\mathrm{HC}$ are the phenomenon to be studied, we opted for the conventional content analysis $^{(1,16)}$. The software MAXQDA ${ }^{\odot}$, version 12.2.0, was used for data treatment.

The definition of the preliminary categories was guided by the theoretical framework adopted in the study (Jean Watson) and the identification of the themes addressed in the interviews and observations. Thus, a first set of categories and subcategories was built. Subsequent to this definition, three interviews were explored and codified. The categories were reviewed and the themes were homogeneous when the categories and/or subcategories were analyzed separately and also their heterogeneity when compared to each other. Then, the same interview was codified by two different researchers, so the agreement between coding was verified, comparing the documents. One of the researchers followed up on coding, discussing situations of doubt in the attribution of the code with another team member.

Based on an analysis and interpretation of each coding group, the empirical category "Palliative care production in home care" was constructed.

\section{RESULTS}

Four nurses, three doctors, a speech therapist, a physiotherapist and four NT participated in the interviews and observations, totaling 13 participants. Participants were predominantly female (69\%), aged between 31 and 58 years old. The time at HCS was between 7 months and 1 year ${ }^{(1)}$.

\section{Palliative care production in home care}

The data produced made it possible to identify care actions that reveal how health professionals identify and perform palliative care in HC. Such care is sometimes presented as measures of maintenance and accompaniment to people in palliative care in the establishment of openness of professionals to dialogue and "listening" to caregivers and users, in carrying out guidelines for the care process, in technical procedures, delivery of materials, referrals and offering medical prescriptions to users ${ }^{(1)}$.

Openness to communication with users and family members was revealed when health professionals were asked about their palliative care actions. For some health professionals (E1, E7), allowing users and caregivers to position themselves as part of care through questions and notes is a palliative care action, as shown in the following fragments ${ }^{(1)}$ :

[...] involving the family in this process [...] listening to the demands [...]. (E1)

[...] we try to talk to the mother, listen to her anxieties [...]. (E7)

Guidance on technical care procedures were evidenced in the observations, in an isolated and individual way, according to the demands of user and their caregivers, without considering the articulation of actions and knowledge of different professionals in a directed care plan ${ }^{(1)}$.

[...] nurse: pee, ok? It's red, but less than that day before, that's right, it must be giving him more water, right? Daughter: yes, just like you guided me. Nurse: does he have contact with the sun here in bed? You need to sunbathe to improve the injury even faster. (FD.p17)

In the moments of the interview, when there was an attempt to deepen about what the interviewees advised in relation to palliative care actions, they focused on information about the moments of death and post-death itself, not contemplating actions for the 
relief of symptoms and QoL to people eligible for palliative care and their families, revealing little knowledge about this topic ${ }^{(1)}$.

[...] try to address with the family what may happen, depending on the family, we even address the case of death at home, because we have this support from the doctor to carry out the death declaration in our user who dies at home [...]. (E2)

Participants evidenced, in the interviews, the importance of guidelines for the care of users and their families in palliative care practice in the context of HC. However, dissonances about these statements were identified in the observations made during home visits, since users, or family members sought to address doubts with health professionals regarding care and were not responded to ${ }^{(1)}$.

[...] E10 it is advised that the decubitus changes happen more often. Exercises with the user are performed, but family members who are curious to learn. are not guided Son: could you teach me this exercise? E10: another time I'll be back for this. [...]. (FD.p36)

Professional guidance on promoting health for home caregivers was also identified, as shown below ${ }^{(1)}$ :

[...] nurse: what about your appointment, mom? Doctor: you need to take care of you too. [...] mother only listens. [...] nurse: be careful, mom, you need time foryou, you have to be strong. [...] you have to go to the doctor, you have to go, you are not okay. Doctor: the burden is heavy, you are already taking care of it, but do not handle everything alone, you are sensitive, allow yourself to be helped. Caregiver [crying]: I can't handle it, it's too much. I am a prisoner of myself. [...]. (FD.p38)

The principles of palliative care include offering support that enables the person eligible for this type of care to live as actively as possible. In this perspective, during a home visit, a child with cerebral palsy was observed, in which the mother exposes her difficulty in making the child and she manage to live actively ${ }^{(1)}$.

[...] doctor:any complaints? How are you, mom? What about school? Caregiver: this week she won't go because she has a phono and OT. I was not able to handle it, because the van can only transport me if it is with me. Then, I had to go take her to school, walk back, then I had to go back to school to have lunch, because school caregivers are afraid of her choking. After 2 hours there, I was going to pick her up again, very tiring. [...] caregiver: the school caregiver is afraid to care. (FD.p38)

The doctor insisted: [...] doctor:yes, going to socialize is important for her, it is a stimulus. You go with her. Nurse: it is very important for her. Doctor: with other children, she will greatly improve socialization [...]. (FD.p38)

The data obtained in this study showed, mainly, conducts aimed at technical procedures, such as dressings, gastric catheter maintenance and delivery of medical prescriptions for drugs to enable palliative care, respectively ${ }^{(1)}$.

[...] nurse: there is dressing, look at the probe and only. (FD.p14)

[...] nurse: let's get to the point, the dressing, how are you changing? (FD.p53)

\section{[...] nursing technician: do you need any prescription? (FD.p17)}

The search for possibilities of care, even though using the creative capacity to offer them, was mentioned in a situation in which the ideal medication or the device for infusing it was not available, establishing a strategy to carry out the control of symptoms, fundamental pillar of palliative care in $\mathrm{HC}^{(1)}$ :

[...] the strategy we do is to try to remedy with what we have; so, if you can't put a fentanyl in the infusion pump, you try to get something oral that can be done in a shorter interval, which, in the case of pain, reduces this inconvenience to the user [...]. (E5)

Using the act of putting oneself in the other's place and doing something that promotes his QoL, a nurse refers to the user as "his son", showing here the use of compassion when putting himself in charge of solving the user's problem in the health system through actions $^{(1)}$.

[...] try to give exactly what she needs, there is no material, I go wherever I go, I go to the councilor, I will make it happen so that my son does not have a lack of material or basic care. So, I think that the perfect is what is possible [...]. (E7)

\section{DISCUSSION}

"Care is everything that comes together in the form of actions or interventions, which collaborate to generate, organize or (re)establish hope, autonomy, freedom of choice in human relationships and the meaning of life" (MARTINES, 2010, 328)(17).

Palliative care is based on the concept of articulation between the intersubjective relationship of different subjects and the use of health technologies, to provide dignity to the person affected by a life-threatening disease, promoting the prevention, control and relief of symptoms. Palliative care requires, fundamentally, good communication, prevention and relief of symptoms, requiring efficient coordination of the care process ${ }^{(1,18)}$.

Considering that interpersonal relationships are essential for those dealing with palliative care, it is essential to know the expectations, fears and anxieties of people with life-threatening illnesses, as well as their caregivers, especially through listening and dialogue. Communication in the context of care is a therapeutic action ${ }^{(1,18)}$.

By understanding people's needs, we enter into their subjectivity and promote welcoming. Thus, the subjectivity of those who are cared for becomes more accessible, allowing interventions that improve their QoL to start as soon as possible $\mathrm{e}^{(1,19)}$.

The dissonance in the communication process identified between the discourse and the observations in home visits can be justified, because it is the home environment, as this is the space of families' private life, which follow a different dynamic from the conventional practices of health services to implement care $^{(1,20)}$. These findings may interfere with the care process, making communication difficult in the context of $\mathrm{HC}$.

Jean Watson's Theory of Human Caring reveals that "being present and supporting the expression of positive and negative feelings" is a necessary element for health professionals to exercise communication and care with quality. For this, it is necessary to develop and maintain the relationship of help-trust in care, using the practice of kindness, 
giving openness to listen to each other. When the fears, desires and yearnings of the cared person and/or their family members are revealed through communication, professionals become responsible and co-responsible for the planning of care actions capable of healing the balance and harmony of these people, as pointed out Watson. By providing this balance and harmony, we contribute to the QoL and human dignity of people with a life-threatening illness or condition, which are goals of palliative care ${ }^{(1,21)}$.

Communication during palliative care in $\mathrm{HC}$, through guidance to users and caregivers, seeks to ensure the quality of continuity of care, allowing the connection of information, generating a therapeutic and reliable environment over time. For this, it is necessary that the managers of the services involved in care actions understand and offer adequate and flexible conditions for the development of work processes, offering ways for health professionals to be able to look at the person being cared for in its uniqueness, promoting $\mathrm{QoL}$ and human dignity ${ }^{(1,21-22)}$.

Ordinance 825 of April 25, 2016 of the Ministry of Health of Brazil, which deals with $\mathrm{HC}$ within the scope of SUS, dictates, in its Article 7, that $\mathrm{HC}$ is responsible for: identifying, guiding and training users' caregivers in care, involving them in the provision of care, respecting their limits and potential, considering them as subjects of the process, welcoming the demand for doubts and complaints from users, family members or caregivers ${ }^{(1,7)}$. In other words, it is part of the care process in $\mathrm{HC}$ to provide guidelines that guarantee continuity of care ${ }^{(1)}$.

For this, the guidelines should not be restricted to mechanistic action, in the sense of teaching procedures, guiding risks and advising care modes; they must raise interest, commitment, responsibility, interaction and satisfaction on the part of those who teach how to care and who provide care ${ }^{(1,23)}$. Therefore, it is necessary that the oriented person, to perform the action, feel a significant and essential part in the care process ${ }^{(21)}$.

Engaging in the genuine teaching-learning experience, which meets the unity of being and meanings, trying to remain in the referential of the other, makes it possible to offer support, in order to meet caregivers' and users' doubts and needs in learning to care or self-care, respectively ${ }^{(1,21,24)}$.

One of the fundamental principles of palliative care is "to offer a support system to help family members during users'illness"(6), and one of the ways to offer this support happens through effective guidelines for care in the home and availability of telephone contact to clarify problems and doubts ${ }^{(1)}$.

It was observed, in this study, that the team understands the need to guide practical activities that allow the person to live more actively until his death, however the caregivers point out difficulties for this action to happen. Therefore, health professionals, equipped with technical concepts of the biomedical care model, trained to comply with strict protocols, do not continue with innovative guidelines and strategies that facilitate palliative care actions at home ${ }^{(1,20)}$. This reveals the distance between the prescribed work and the real work in certain activities in the health care process.

The prescribed work concerns everything that has been previously established before the act takes place, including standards, care techniques and the disposition of the environment to perform the task. The actual work is what actually happens in practice, in the reality of each local, in its singularity ${ }^{(1,25)}$. It is understood that performing care in practice is something intricate, especially with regard to providing guidance for others to do, because it is a dynamic and relational process between people, in which the prescribed work and the real work are confronted continuously. However, it is necessary to advance in methods and strategies that go beyond protocols, guidelines, manuals, etc., so that the prescribed work is able to materialize in care actions, i.e., in the real work ${ }^{(1)}$.

At times when the caregiver is directly influenced by the pain of someone in emotionally sensitive conditions, such as those eligible for palliative care, and, by trying empathetically to help them and live with such a situation, these people may develop a state of mental suffering named fatigue out of compassion ${ }^{(1,26)}$. It should be noted that fatigue due to compassion may be closely related to the lack of appropriate guidance and support for these caregivers, generating overload in addition to physical and emotional(1).

One of the central elements of palliative care practice is compassion - the ability to understand the other's conditions, characterized by actions of care in the face of this perception ${ }^{(5)}$. Acts of compassion associated with professional practices sustained in disciplines, i.e., extended areas of knowledge, qualify care actions beyond a restricted act of charity. Compassion has the ability to reveal positive aspects of affection in the experience of helping other people, causing significant and relevant effects in the practice of care. This condition is called satisfaction for compassion ${ }^{(1,26-27)}$. The act of qualitatively guiding caregivers to provide care reveals compassion for the other in their context.

Health professionals must use creativity, using strategies based on theoretical and practical knowledge learned in the academy, professional and life experiences, intuition and common sense to perform care actions that are sometimes not included in existing theoretical resources ${ }^{(1,21)}$. The use of creativity, in addition to creating strategies that will support caregivers to provide assistance with higher quality and safety at home and in their living environments, will also allow creating conditions for the person to live as actively as possible until the moment of their death ${ }^{(1)}$.

$\mathrm{HC}$ presumes to take care in a way that goes beyond the exclusively curative aspects of the disease that affects users. It promotes changes in the production of health care, valuing aspects and meanings of human existence, such as cultural, historical, social, psychological and spiritual issues, without abandoning the physical aspects, commune with the intentionality of palliative care. However, the data obtained in this study showed, predominantly, conducts basically focused on technical and logistical procedures to enable palliative care in HC. And even for that, for the work process to flow with quality, material resources are fundamental ${ }^{(1,28)}$.

In palliative care, these material resources do not differ from the resources for other practices in HC. However, in people with advanced and terminal illnesses, the time of availability of the material for the provision of care is fundamental for the promotion of QoL and, consequently, of human dignity, considering life-threatening conditions that users face ${ }^{(1,28)}$.

The organizational dimension of care treats the organization of the work process as fundamental in guaranteeing quality of care. The definition of health care flows and rules and the adoption of work tools, such as agendas, protocols, material control spreadsheets, team meetings, visits, evaluation, etc., favor the organization of health work, preventing, among other issues, the lack of necessary 
materials for the provision of care. The scarcity of material and organizational resources that enable the organization of work processes significantly hinder the provision of palliative care at home, placing users and family members in vulnerable conditions of suffering ${ }^{(1,29)}$.

In order to promote comprehensive care, it is necessary to offer the right conditions so that it is provided continuously. Extending beyond the aforementioned material and organizational resources, Watson proposes an awareness of care that contemplates the totality of being, creating an environment of reconstruction (healing), in which comfort and dignity are contemplated through biopsychosocial and spiritual care ${ }^{(1,21)}$.

The establishment of an individualized therapeutic plan allows the establishment of care objectives and, through them, necessary guidelines for the promotion of palliative care in $\mathrm{HC}$, providing QoL ${ }^{(1,30)}$. Indicated through the Brazilian National Humanization Policy (PNH - Política Nacional de Humanização), the Unique Therapeutic Project is relevant in the systematization of palliative care in $\mathrm{HC}$, by proposing the construction of a care plan that defines actions from the perspective of subjects' uniqueness watched ${ }^{(1,30)}$. However, it is noteworthy that the therapeutic plans are dynamic, carried out by a multidisciplinary team, involving users and their caregivers, in addition to requiring constant reevaluations and remodeling ${ }^{(1)}$.

The incipience of care beyond the physical dimension highlights the need to expand the context of care. The use of actions aimed at spiritual care increases the possibility of promoting QoL and human dignity to people affected by life-threatening conditions, re-balancing the meaning of life. To promote care by addressing the spiritual aspects of users and their caregivers, it is necessary for health professionals to understand that, in order to offer QoL, in addition to good practices aimed at physical, social and psychological care, it is important to know the life of those who are cared for, i.e., what is sacred to them, what transcends, what gives meaning to their lives. It becomes possible, therefore, through qualified listening, the perception and clarity of realistic hope, in order to rebalance expectations and life goals of users and caregivers, providing inner peace, well-being and spiritual health (healing) $)^{(1,31)}$.

The Clinical Caritas Process, postulated by Jean Watson, treats care as something precious and sacred, understanding that, in order to care for someone, we need to enter their phenomenological field and understand individuals and "their world", assisting them, in their entirety, through transpersonal care. In this way, it is possible to know their essence, their fears, desires and yearnings, understanding the person in their entirety ${ }^{(1,10,32)}$.

The realization of palliative care in $\mathrm{HC}$, object of this study, brings the philosophy of palliative care even closer to transpersonal care, considering that the home environment is the place of the most intimate of people, it is "their world". The home is the place where a person's essence, their "I", is closer to fullness, facilitated by privacy and familiarity with the environment. When $\mathrm{HC}$ health professionals, in the use of the awareness of human care, based on love, interact with people in this "their world", they create an environment of human healing ${ }^{(1)}$.

The healing environment is created as care is provided, the help-trust relationship is established and, according to health professionals, the human being is cared for in their physical, psychosocial and spiritual aspects, in addition to those involved in their care and the environment that surrounds them ${ }^{(1,33-34)}$.
Watson argues that the act of caring involves values, will, commitment to the other, knowledge and actions of empathy and love, with the purpose of protecting, improving and preserving the dignity of a person and their environment ${ }^{(21)}$. By diversifying the focus of care from its technical act of mastery over technology and the biological aspects of care to a more altruistic perspective, we approach people with greater effectiveness and totality, healing their health, QoL or even when the disease that afflicts them has no cure, a dignified death ${ }^{(1,34-35)}$.

The definition of Watson's Clinical Caritas Process elements aimed to guide the practice of health professionals so that they recognized the person in need of care as sacred ${ }^{(1,21)}$ and that these professionals could, through their transpersonal interaction, to know the needs of those they care for, contributing to healing this being.

\section{Study limitations}

Considering the importance of the results obtained, the study presents as a limitation that it was carried out in a restricted setting, including only one Brazilian municipality. It is important that other studies are developed in different municipalities in the country so that it is possible to understand the diversity of actions of health professionals working in $\mathrm{HC}$, in palliative care, explaining a contextualization as Brazil.

\section{Contributions to nursing, health, and public policies}

The findings point to the urgent need for advances in the creation and implementation of government policies in Brazil for the insertion of palliative care in RAS. Moreover, it is necessary that this policy supports educational actions, either through introducing palliative care teaching in the different levels of training of health professionals or through actions of permanent education in health, favoring $\mathrm{QoL}^{(1)}$.

\section{FINAL CONSIDERATIONS}

The narratives of this study revealed that care actions emerged from experiences of encounters between professionals, family caregivers and users at home. Health professionals develop communication and guidance actions for $\mathrm{HC}$ and symptom control. However, such actions are insufficient with regard to the humanistic principles of palliative care recommended by the WHO and the theoretical and practical precepts evidenced by the scientific literature about this modality of care ${ }^{(1)}$.

This insufficiency is justified by the fragility of professionals' training and knowledge on palliative care, making them give priority to physical aspects of care; and deficiency of public authorities and health managers in providing conditions that ensure comprehensive care and a palliative approach ${ }^{(1)}$.

\section{SUPPLEMENTARY MATERIAL}

This study originated from the Doctoral Thesis entitled The production of palliative care in the context of home care, linked to the Postgraduate Program in Nursing at the Federal University of Minas Gerais: http://hdl.handle.net/1843/ BUOS-B4GFE9. 


\section{REFERENCES}

1. Silva EA. A produção de cuidados paliativos no contexto da atenção domiciliar [Tese]. Belo Horizonte: Universidade Federal de Minas Gerais; 2018. 169p.

2. Marcucci FCl, Cabrera MAS. Morte no hospital e no domicílio: influências populacionais e das políticas de saúde em Londrina, Paraná, Brasil (1996-2010). Ciênc Saúde Colet. 2015;20(3):833-40. https://doi.org/10.1590/1413-81232015203.04302014

3. Simieli I, Padilha LAR, Tavares CFDEF. Realidade do envelhecimento populacional frente às doenças crônicas não transmissíveis. Rev Eletrôn Acervo Saúde. 2019;(37):1511-11. https://doi.org/10.25248/reais.e1511.2019

4. Saito DYT, Zoboli ELCP. Cuidados paliativos e a atenção primária à saúde: scoping review. Rev Bioética Brasília. 2016;23(3):593-607. https:// doi.org/10.1590/1983-80422015233096

5. Capelas MLV, Coelho SPF, Silva SCFSD, Ferreira CMD. Cuidar da pessoa que sofre: uma teoria de cuidados paliativos. Lisboa: Universidade Católica Editora; 2017. 88 p.

6. World Health Organization (WHO). Palliative care [Internet]. 2017[cited 2017 Oct 13]. Available from: http://www.who.int/mediacentre/ factsheets/fs402/en/

7. Alves RF, Andrade SFO, Melo MO, Cavalcante KB, Angelim RM. Cuidados paliativos: desafios dos cuidadores e profissionais de saúde. Fractal: Rev Psicol. 2015;27(2):165-76. https://doi.org/10.1590/1984-0292/943

8. Ministério da Saúde (BR). Portaria n 825, de 25 de abril de 2016. Redefine a Atenção Domiciliar no âmbito do Sistema Único de Saúde (SUS) e atualiza as equipes habilitadas [Internet]. Diário Oficial da União, Brasília. 2016[cited 2017 Oct 13];(78):3338. Available from: http://www. jusbrasil.com.br/diarios/113894163/dou-secao-1-26-04-2016-pg-33

9. Ministério da Saúde (BR). Secretaria de Atenção à Saúde. Departamento de Atenção Básica. Caderno de atenção domiciliar. Brasília (DF): Ministério da Saúde. 2012.

10. Tonin L, Nascimento JD, Lacerda MR, Favero L, Gomes IM, Denipote AGM. Guia para a realização dos elementos do Processo Clinical Caritas. Esc Anna Nery. 2017;21(4):1-7. https://doi.org/10.1590/2177-9465-ean-2017-0034

11. Ministério da Saúde (BR). Conselho Nacional de Saúde. Resolução n. 466, de 12 de dezembro de 2012. Aprova diretrizes e normas regulamentadoras de pesquisas envolvendo seres humanos [Internet]. Diário Oficial da União, Brasília, 13 jun. 2013 [cited 2017 Oct 13]. Available from: http://bvsms.saude.gov.br/bvs/saudelegis/cns/2013/res0466_12_12_2012.html

12. Yin RK. Estudo de caso: planejamento e métodos. 4a ed. Porto Alegre: Bookman, 2015. 290 p.

13. Marconi MA, Lakatos EM. Técnica de pesquisa. 7a ed. São Paulo: Atlas, 2008.

14. O'Reilly M, Parker, N. Unsatisfactory saturation: a critical exploration of the notion of saturated sample sizes in qualitative research. Qualit Res. 2012;13:190-7. https://doi.org/10.1177\%2F1468794112446106

15. Rossi GB, Serralvo FA, João BN. Análise de conteúdo. Rev Bras Market. 2014;13(4):39-48. https://doi.org/10.5585/remark.v13i4.2701

16. Hsieh H, Shannon SE. Three approaches to qualitative content analysis. Qualit Health Res. 2005;15(9):1277-88. https://doi. org/10.1177\%2F1049732305276687

17. Martines WRV, Machado AL. Produção de cuidado e subjetividade. Rev Bras Enferm. 2010;63(2):328-33. https://doi.org/10.1590/ S0034-71672010000200025

18. World Health Organization (WHO). Better palliative care for older people: Europe [Internet]. 2004[cited 2017 Oct 13]. Available from: http:// www.euro.who.int/data/assets/pdf_file/0009/98235/E82933.pdf

19. Duarte LPDA, Moreira DJ, Duarte EB, Feitosa ANC, Oliveira AM. Contribuição da Escuta Qualificada para a Integralidade na Atenção Primária. Rev Eletrôn Gestão Saúde. 2017;8(3):414-29. https://doi.org/10.18673/gs.v8i3.24185

20. Pires MRGM. Politicidade do cuidado na perspectiva de gênero: das políticas de saúde às práticas da/o enfermeira/o na APS. In: Ferreira RJ, Périco LAD, Dias GV, (Org.). O Trabalho do enfermeiro na Atenção Primária à Saúde. Rio de Janeiro: Atheneu; 2017;1:93-110. https://doi. org/10.1590/0034-7167-2016-044

21. Watson J. Watson's theory of human caring and subjective living experiences: carative factors/caritas processes as a disciplinary guide to the professional nursing practice. Texto Contexto Enferm. 2007;16(16):129-35. https://doi.org/10.1590/S0104-07072007000100016

22. Baratieri T, Marcons SS. Longitudinality of care: perceptions of the nurses that work at the Family health strategy. Esc Anna Nery. 2011;15(4):802-10. https://doi.org/10.1590/S1414-81452011000400020

23. Hermes HR, Lamarca ICA. Cuidados paliativos: uma abordagem a partir das categorias profissionais de saúde. Ciênc Saúde Colet. 2013;18(9):257-8. https://doi.org/10.1590/S1413-81232013000900012

24. Rabelo ACS, Souza FVFS, Silva LF. Contribuição do cuidado transpessoal ao ser cardiopata no pós-operatório de cirurgia cardíaca. Rev Gaúcha Enferm. 2018;38(4):64743. https://doi.org/10.1590/1983-1447.2017.04.64743

25. Castro DMM, Oliveira SS. Avaliação do trabalho na Atenção Primária à Saúde do município do Rio de Janeiro: uma abordagem em saúde do trabalhador. Saúde Debate. 2017;41(especial):152-164. https://doi.org/10.1590/0103-11042017S213 
26. Santos ACO. Satisfação das necessidades psicológicas básicas satisfação e fadiga por compaixão e atitudes perante a morte em enfermeiros[Dissertação] [Internet]. Escola de Psicologia e Ciências da Vida Universidade Lusófona de Humanidades e Tecnologias, Lisboa, 2016[cited 2017 Oct 13]. Available from: http://recil.grupolusofona.pt/bitstream/handle/10437/8392/Tese\%20Ana\%20Santos\%20Final\%20 com\%20j\%c3\%bari.pdf?sequence=1.

27. Figley CR. Compassion fatigue: psychotherapist's chronic lack of self-care. J Clin Psychol. 2002;58(11):1433-41. https://doi.org/10.1002/ jclp.10090

28. Silva KL, Sena RR, Seixas CT, Feuerwerker LCM, Merhy EE. Atenção domiciliar como mudança do modelo tecnoassistencial. Rev Saúde Pública. 2010; 44(1)166-76. https://doi.org/10.1590/S0034-891020 10000100018

29. Cecílio LCDO. Apontamentos teórico-conceituais sobre processos avaliativos considerando as múltiplas dimensões da gestão do cuidado em saúde. Interface (Botucatu). 2011;15(37):589-99. https://doi.org/ 10.1590/S1414-32832011000200021

30. Assega ML, Lopes-Jr LC, Assega DT, Lima RAG, Pirolo SM. Projeto terapêutico singular e equipe multiprofissional no manejo de caso clínico complexo: relato de experiência. Rev Enferm UFPE. 2015;9(4):7482-88. https://doi.org/10.5205/reuol.7275-62744-1-SM.0904201537

31. Evangelista CB, Lopes MEL, Costa SFG, Abrão FMS, Batista, PSS, Oliveira RC. Spirituality in patient care under palliative care: a study with nurses. Esc Anna Nery. 2016;20(1):176-82. https://doi.org/10.5935/1414-8145.20160023

32. Watson J. Nursing: the philosophy and science of caring. Colorado: University Press of Colorado. 2008; 321p.

33. Clot Y. A função psicológica do trabalho. Petrópolis: Vozes; 2006. 222p.

34. Revels SA, Goldberg L, Watson J. Caring Science: a theoretical framework for palliative care in the emergency department. Int J Human Caring. 2016;20(4):206-12. https://doi.org/10.20467/1091-5710.20.4.206

35. Gomes IM, Silva DDI, Lacerda MR, Mazza VDA, Meier MJ, Merces NN. Teoria do cuidado transpessoal de Jean Watson no cuidado domiciliar de enfermagem a criança: uma reflexão. Esc Anna Nery. 2013;17(3):555-61. https://doi.org/10.1590/S1414-81452013000300021 